\title{
Professional Feminists: Challenging Local Government Inside Out
}

Gender, Work and Organisation 2018

\section{Freya Johnson Ross}

UCL Institute of Education 36 Gordon Square, London WC1H OPD, United Kingdom

\section{Abstract}

Gender equality work in local government carried out during the 1980s presents a valuable site to explore the interaction between professional and feminist working. In the history of the Women's Liberation Movement (WLM) and feminist organising more broadly in the UK, professional working has often been positioned as antithetical to feminist working, and relatively little scholarship has examined the interface between the two. This article argues that the individuals involved should be considered 'professional feminists' as opposed to 'femocrats', drawing from across feminist, social movement and organisational theory, and interviews carried out in 2011 and archival texts from three UK councils. It also suggests their work (undertaken between the beginning of the 1980s and beginning of the 1990s) serves to blur the boundaries usually marked between social movement and state. This contributes to the extant literature by exploring the specific understandings and practices put to work by those working on gender equality professionally, but not in an elected capacity, within local government, and how their work can be positioned in relation to feminist organising more broadly.

Key words: professional feminists; gender equality; local government; femocrats

\section{Introduction}

This article examines UK local government gender equality workers during the period of 'municipal feminism' in the 1980s and positions them in relation to feminism, the feminist movement, and theorising about those working within formal, though significantly not political or activist, channels to further gender equality. There are several areas of scholarship 
which frame this discussion; theorising about feminism, about social movements, and about organisation. Yet local government gender equality work does not sit neatly within any of these, requiring an approach drawing across them. Generally, gender equality initiatives in UK local government have not been regarded as a significant part of the history of feminist activism. Underplayed in the literature (MacKay 2008), they have been viewed by social movement theorists as an institutionalised element stemming from the WLM, and 'femocrat' (feminist bureaucrat) is the closest descriptor developed that has or could be applied to their workers. My data and analysis focused on the micro level and practices of local government gender equality workers complicates these ideas in several ways. I use this to theorise them as 'professional feminists' neither fully inside nor outside the state. Professional feminists are characterised by: feminist knowledge of gender inequality; their paid 'challenge position' in relation to the ideas and organising of their institutional location; and their motivation to bring practical change to people's lives. My analysis draws the individuals of the initiatives closer to the WLM in terms of issues addressed and ways of organising this, blurring the line between social movement and state - which for feminism in particular has been significantly debated. Secondly, it highlights the way in which the workers go beyond the ascription of femocrat to challenge their institutional location and its organising. Thirdly, I suggest that the orientation of the workers to making practical change presents a way both to connect them to the WLM, but also to link the feminist with the professional. In doing so this article contributes to a rebalancing between what has at times been presented as 'proper' feminism (autonomous groups of the WLM) and those seeking change through and within institutions (Periton, 2007) in the context of this period of UK history. This also arguably contributes to the presentation of a nuanced picture regarding the evaluation of different strands and modes of feminist working, alongside work which has already taken place on the theorisation of state feminism and feminist institutionalism. Rather than viewing authenticity as residing in a particular locale, the working of 'professional feminists' can be viewed as one element within a constellation of approaches contributing to the furthering of gender equality. This also reflects the value in analysing strategies for social change using multiple disciplinary lenses, as adopted here, enabling a more rounded and balanced perspective.

\section{Feminism and Professionalism}


Scholarship on feminism and its history in the UK has tended to position feminist activity as antithetical to professional working and modes of organising, and equate it with very specific non-hierarchical, collective approaches. For example, central works on the WLM (for example, Rowbotham, 1979, Coote and Campbell, 1982, Bouchier, 1983) suggest this strongly, highlighting consciousness raising and prefigurative politics as core to its distinctiveness in contrast to modes of professional organising associated with politics or business. The problematics of feminist organising, and the dominant account of what this is constituted by, was not unquestioned. For example with Freeman (1970) as early as 1970 drawing attention to difficulties with 'unstructured', nonhierarchical organising, and Acker (1995) highlighting the limits of participatory democracy and problems faced by feminists and others committed to egalitarianism. Yet little work has examined the points where, or how, feminism and professionalism (outside of formal politics) might interact, despite growing acknowledgement and attention being given to the significance of institutions as conduits for gender equality work (Threlfall 1996, MacKay 2008). Unusual examples include Sarah Green's study which includes discussion of the increasing number of lesbian feminists employed in a professional capacity in London (Green, 1997), and Cowman and Jackson who consider the ambivalence in relation to women's professional identities in the first half of the $20^{\text {th }}$ century (Cowman and Jackson, 2005). Perriton has also raised questions about their opposition, and the representation of this within scholarship while examining the British Federation of Business and Professional Women from the post-war period until the 1960s (Perriton, 2007).

\section{Feminism and the State}

This is arguably also related to the close yet ambivalent relationship between feminism and the state in the history of UK feminist theory and activity, which has received more attention. The early WLM was critical and suspicious of male dominated mainstream politics and the state (Cockburn, 1977, Rowbotham, 1996), yet also engaged it as a key interlocutor with its demands (Randall, 1998). Subsequent decades have seen the development of nuanced accounts of the state and this relationship as I discuss later, and indeed the development of a significant body of work on 'state feminism' where states are seen to act in a quasi-feminist manner (Mazur and Stetson, 1995, Outshoorn and Kantola, 2007, McBride and Mazur, 2010), which continues to evolve (for example, Kantola and Squires, 2012). Yet this has 
tended to focus on the level of national (or national comparisons) and policies and mechanisms for gender equality, as opposed to the actors involved in this, their working practices, or what takes place at regional or local level. For example, Mazur and Stetson examine how state structures contribute to the formation of feminist policy. Lovenduski (2007) has examined this in the UK, tracing the development of national gender equality policy and related machinery. Although she does consider this somewhat in its relationship to the women's movement - this is not its focus, nor the positionality of the workers within the state. Thus although state feminist approaches provide useful insights into the structures, policy and significance of national state apparatus for gender equality, which is arguably partly illustrated by municipal feminism, they don't provide a framework for looking at professional/feminist interactions within a differentiated nation state, the local practice of individual workers as opposed to elected representatives, or how we should understand these individuals in the wider context of feminist activity.

\section{Local Government Gender Equality Work}

Work in local government on gender equality presents a useful site to examine this professional/feminist nexus; as it involves paid workers (as opposed to politicians) in traditionally bureaucratic organisations, addressing feminist issues. Councils have been seen as primary examples of bureaucratic organisations (Brownill and Halford, 1990, Halford, 1992) - characterised by hierarchy of authority, a clear system of rules, impersonality, efficiency and employment based on technical qualification (Blau, 1956). This characterisation of bureaucracy developed by Weber does have limitations, including its failure to explain the ways in which bureaucratic organisations can be inefficient, and lack of attention to the informal dynamics of an organisation (Halford 1992). However, it does still remain useful in thinking about the organizational features of councils during the municipal feminist period, particularly in highlighting some of the features which clashed with the working of women's initiatives.

The 1980s witnessed a key point in the development of local government gender equality work. Scholarship at the time documented the occurrence of 'municipal feminism' from 1979 to the mid 1990s (for example, Button, 1984, Goss, 1984, Edwards, 1988, Edwards, 1989, Harriss, 1989, Brownill and Halford, 1990, Halford, 1990, Halford, 1992, Bruegel and Kean, 1995, Edwards, 1995). However, there has been little attempt subsequently to analyse and 
situate this period of work specifically in relation to feminist activism or theorising about those carrying it out. Its documentation has largely reflected an ongoing tendency towards descriptive, reflective accounts - arguably mirroring earlier tendencies within the history of the WLM in the UK (Scott, 2002, Wright, 2002). Stokes' (Stokes, 1998), Halford and Leonard (Halford and Leonard, 2001) and Bashevkin (Bashevkin, 2006) are notable exceptions. Stokes examined what remained formally of women's initiatives in 1995, but with a focus on the political committees and representative dimensions of these in contrast to my analysis focusing on the working and understandings of the non-political actors. Halford and Leonard include reference to municipal feminist workers, suggesting they acted as femocrats - yet the working of these actors is not the main focus of their analysis of gender and organisations. Bashevkin's work is useful in considering the longer term impact of municipal feminism in terms of women's contemporary representation in London and Toronto. However, her analysis does not focus on considering how we should theorise the individuals involved, and their understandings and practices, in relation to feminist organising.

\section{Theorising Feminists Working in Other Institutional Contexts}

Other work which has sought to understand the working of those within and between seemingly conflicting ideas and contexts includes Katzenstein's work in the US church and military (1998), Ebyn and Turquet's examination of feminists in development (Eyben and Turquet, 2013), and Meyerson and Scully's notion of ‘tempered radicalism' (2003). Yet, although providing illustrations of where and how women have sought to create change within non-feminist institutions, their focus is not on institutions of the state or local government, and stresses alliance to institutional location, as well as feminist aims. Research developing and exploring the notion of the 'femocrat', defined as a feminist bureaucrat (Eisenstein, 1995) has come closest to considering municipal feminism theoretically (for example, Franzway, Court et al., 1989, Eisenstein, 1995, Eisenstein, 1996, Chappell, 2002). Eisenstein's work has focused on national level actors in the Australian state - and she argued using their personal accounts against the notion that state or bureaucratic organising was fundamentally unfeminist. She suggests positive gains can be won for women in this way, but warns against the erosion of links between these actors and feminists outside state mechanisms. She suggests the categories of the bureaucratic individual, and the bureaucratic 
structural (Eisenstein, 1989, Eisenstein, 1991), the first where women enter state policy making as self-identified feminists and the second where women create new structures within government to benefit women. Yet, I use my data to propose that the municipal feminist workers also challenge and work to change the organising of the councils in relation to gender equality. Chappell has also considered national level actors in the UK comparatively with Australia and Canada, yet does not deal in detail with local government. Significantly she suggests the lack of efficacy of femocrats in the UK is the result of feminist suspicion of the state, and as I have also suggested, little literature addressing this. Literature has suggested 'femocrat' used in relation to local government gender equality workers was deemed negatively (Bruegel and Kean 1995). Watson discussed the association with careerism and 'selling out' which was commonly voiced (1992), and Franzway et al argue in the UK it was deemed to be seen as a betrayal of ideals (1989). I investigate these ideas in relation to my empirical data, suggesting that the workers of the municipal feminist period are not fully described by the notion of the femocrat. I develop the concept of the 'professional feminist' as a way to theorise their position and working in relation to feminist activity, organising and the state.

In order to develop the notion of the professional feminist I draw on the work of Jonathan Dean and Rosi Braidotti, as well as insights from theorists with an organisational focus, to understand the significance of this subject position in the context of feminist activity more widely. Dean proposes radicality within feminist activity should be linked to its worldbuilding capacity, as opposed to its location (2010). It is suggested this has historically been the case in relation to feminist activity, leading to particular locations (for example, non-state, autonomous spaces) being regarded as inherently more radical than others. This notion can contribute to loosening the rigidity of the categorisation of feminist activity in relation to professional working which I seek to develop here. Here too, Braidotti's (2002) notion of the nomadic subject as neither insider nor outsider, but dynamic and changing is insightful. Drawing from my empirical data I develop a framework for defining the distinctive elements of the 'professional feminist'. These are: feminist knowledge of gender inequality, their paid 'challenge position' in relation to the ideas and organising of their institutional location, and their motivation to bring about practical positive change in people's lives. This combination means they work to envision new ways of understanding and organising the work of the council in relation to gender equality, without being fully aligned with the institution or with activists outside it. To understand the significance of this mode of making change through 
their professional location I have also integrated insights from work which has examined the process of social change through organisations, such as (Zald, Morrill et al., 2005) and (Lombardo, Meier et al., 2009).

These elements of professional feminism cut across the well established delineations in the analysis of the feminist movement, with important connections and distinctions. The application of feminist knowledge, ways of organising traditionally associated with the WLM, and a focus on material outcomes are key links to the feminist movement. On the other hand, paid working within an institutional setting is also a distinct path from activism addressed to the state from outside. I present the motivation of my interviewees to work on changing material outcomes as a useful way of understanding their rationale for working in an institutional setting, and an important link to the feminist movement.

\section{Method}

In order to examine the positioning of the council gender equality workers I developed a sample of three sites of local government (categorised as the pioneering council, enthusiastic follower, and late adopter based on the time period in which they first developed their women's initiative). This was constructed to represent a spread of the political and organisational conditions of the period for such initiatives, as I was investigating this inception in relation to how gender equality work has subsequently developed over time (which I have addressed elsewhere). I drew on earlier work by Susan Halford (Halford, 1990) which mapped the occurrence of municipal feminism in the UK in doing so. The present article focuses primarily on the interview data collected from the three sites, from the period in which they first developed their women's initiatives. The pioneering council was a Labour-led borough council in London, which formed its women's initiative quickly at the start of the 1980s. The smallest of the three sites, its local population was ethnically diverse, with high levels of deprivation. The enthusiastic follower council was a Labour-led city council in the South-West, which formed its women's initiative in the mid-1980s. It is larger, though less ethnically diverse and relatively less deprived that the pioneering council. The late adopter council is a Labour-led city council in the North, which did not develop its women's initiative until the beginning of the 1990s. It is the largest in terms of population, the least ethnically diverse, with levels of deprivation between those of the other two sites. In terms of the political context the women's initiatives were operating in, it is worth noting that 
although all three sites were Labour-led during the period under study, as Halford's work previously illustrated, this does not equate to uniformity in relation to work on gender. Halford's work examined the relationship between contextual factors, including political conditions, and the occurrence of women's initiatives - in contrast, the focus of the present article is on the micro-level of ideas and approaches to work of the individuals within these.

At each site I undertook semi-structured interviews (lasting around an hour) with three key gender equality workers who had been present at the council during the period in which the women's initiatives were created. As my research is focused on the mid-space between formal politics and outsider activism, the interviews focused on those individuals involved as workers, rather than elected councilors. However, I did interview one councillor in each site, as the literature suggested they played a significant role in the initial establishment of the initiatives and so were key informants on their working. Texts relating to the councils' work on gender equality (including policy texts, reports, and job specifications) were gathered using council records, and local archives, as well as supplemented by documents retained by interviewees themselves. This involved extensive searches in person and threw up considerable challenges, including identifying and locating sources and in finding comparable documentation. In some cases little had been retained within council records, and particularly little in relation to the organisation and principles of the initiatives as opposed to recorded political minutes - making other local archives and documentation from interviewees extremely valuable. All interviews and texts were transcribed in full and analysed using NVivo.

In analysing the data I drew insights from discourse analysis and hermeneutic theorising (Foucault, 1972, Parker, 1992, Cerwonka and Malkki, 2007, Allan, 2008). These are useful in recognising both the constructed and constituting nature of 'talk' about gender equality, and the need to consider this talk in its broader institutional, historical and socio-political context when seeking to understand it. On the one hand, a Foucauldian perspective regards discourses as historically specific systems of meaning, both reflecting and shaping social relations. This was something I brought to my data analysis in considering how individuals and other forms of record understood and reflected on what they were and had done in relation to gender, equality and feminist activity. Yet the material dimension in which discourses are located is also significant, thus rather than elevating either the material or discursive, I was influenced by hermeneutic approaches that encompass both interpretive and experiential elements. This links back to a conception of knowledge as situated, and sees: 
understanding, as distinguished from having correct information and scientific knowledge, is a complicated process which never produces unequivocal results. It is an unending activity by which, in constant change and variation, we come to terms with and reconcile ourselves to reality (Arendt, 2005: 307).

This means that in attending to my data I was aware that on the one hand it contained certain material truths, for example budgets or 'official' lines or policies. Yet on the other hand it also contained multiple and at times conflicting accounts of events and personal motivations. In my mind as I began my analysis I felt clear that neither one of these took priority, particularly as the very point of this research was to consider the understanding and practices of gender equality workers, in the space of interpretation and enaction of legislation, policies and concepts, from an interdisciplinary perspective. The discourse suggesting that feminism and professionalism are antithetical to each other is evident in feminist literature from the 1960s onwards as discussed above, as well as multiple theoretical and historical perspectives on social movements - which makes this particularly interesting to investigate in the context of municipal feminist working. To analyse my data I undertook a process layering inductive and deductive coding, based on the process described by Allan (2008). This involved rounds of coding, review and comparison - in relation to the data sources, my research questions, literature and key theoretical concepts.

\section{Do the Equality Workers Consider Themselves Feminists?}

All of my interviewees considered themselves feminists. However, there was one for whom this was not her most important identity, and another who might not have used the term at the time, but would now. One recounted:

Oh yes definitely, I mean you know that was one of the things that definitely drove, and has driven you know my career, you know yes I am absolutely a feminist, I absolutely believe in women's equality. (Harriet, Women's Officer, Late Adopter Council)

And similarly, discussing whether they would apply the word feminist to themselves two other interviewees commented: 
Oh yeah, yeah yeah yeah no absolutely. You'd have to be wouldn't you, you couldn't, you couldn't survive if you weren't, I can't see why you wouldn't be. (Geraldine, Women's Unit Worker, Pioneering Council)

I'd thought of myself as a feminist ever since I'd thought of myself as anything political. (Emily, Women's Officer, Enthusiastic Follower Council)

These emphatic statements show how important their feminist identity was for interviewees, despite working within the council environment. This was definitely something distinct from party and left-wing politics, rather than necessarily connected to it. This has not always been acknowledged in the literature which has at points equated it to the strong local Labour opposition to central government during this period (Halford, 1990, Travers, 1990), as another interviewee explained:

I regarded myself as a feminist and someone that did strive for women's equality, and women achieving their potential. So that's how I would have described myself. By the time I went to work in the women's unit I wasn't into party politics, I'd left the Labour Party. (Barbara, Women' Unit Worker, Late Adopter Council)

This comment introduces the notion of feminist ideas as at times in tension with party and left-wing politics for the individuals involved, as well as at the macro level of the local and national political scene. However, there were others that did connect their feminism to leftwing politics, for example one describing themselves then, and now, as a socialist feminist.

I did not provide a definition of feminism to my interviewees, leaving it open for them to pick up as they saw fit and flesh out in discussion. Although possibly risking enabling the use of a hollow, content free account of feminism if individuals reported identification unthinkingly, I would argue that this was appropriate to avoid being didactic; given the multiple nature of feminism, and my interest in exploring the boundaries of the feminist movement and its working. As I discuss later, without explicitly asking interviewees to define feminism, we can discern its parameters from their answers.

I would argue that the self-identification of the council workers with feminism is a first key element linking them to the feminist movement. This self-identification has also been reported in scholarship on femocrats - particularly in Australia (Eisenstein, 1995, 1996, Chappell 2002). However, Chappell suggested examining contemporary gender equality workers at national level in the UK that they did not feel able to be open about their feminist 
views - which distinguishes them from my interviewees. However, it is possible that the passage of time may have made them feel more able to be open about this. I now go on to examine in greater detail the extent to which the workers have connections with the Women's Liberation Movement specifically, in terms of their views and actions both inside and outside the council.

Relating the Views and Actions of the Equality Workers to the Women's Liberation

\section{Movement}

To position the municipal workers in further detail, I examined how their feminist views and working relate to the WLM. The WLM in the UK had its roots in the new social movements developing in the 1960s (Harriss, 1989), and involved feminist campaigns on a broad range of different issues, organised in a multitude of ways. Certain topics (epitomised by the seven demands of the movement ${ }^{1}$ ) and certain ways of organising (focused on prefigurative politics and small consciousness raising groups) have come to be seen as epitomising the WLM.

From the perspective of social movement theory, municipal feminist initiatives or their workers are generally not regarded as part of the WLM or the broader feminist movement. This is due to the fact they do not conform to the four criteria outlined by della Porta and Diani (1999): 1) being constituted from informal interaction networks made of individuals, groups and organisations, 2) sharing belief and solidarity as movements seek to introduce new issues or reframe old ones, 3) taking part in collective action, and 4) using protest rather than formalised political channels to express ideas. Instead, they would be regarded as the institutionalisation of the WLM. In the UK the notion of the women's movement becoming institutionalised - formalised and entering into institutions including the state - over time has been repeatedly put forward (Lovenduski and Randall, 1993, Rowbotham, 1996, Walby, 2002). This has also been connected to narratives of 'selling out' or co-optation and deradicalisation at the time as mentioned earlier, and discussed more recently in detail by Dean (2010) and MacKay (2008). Yet, the extent to which this is inevitable remains up for

\footnotetext{
${ }^{1}$ These demands were: equal pay for equal work, equal education and opportunities, free contraception and abortion on demand, free 24 hour nurseries, legal and financial independence, the right to a self defined sexuality and an end to discrimination against lesbians, and freedom from intimidation by threat or use of male violence and an end to the laws, assumptions and institutions that perpetuate male dominance and aggression towards women.
} 
discussion (Saunders, 2009). In the context of this article I seek to suggest that when we examine the views and working of municipal feminists, it is more accurate to regard their 'professional feminism' as an approach within a constellation of approaches to feminist working. A combination of factors has led to particular elements of the WLM's organising coming to characterise it, and the positioning of feminist working as antithetical to a professional context. I would suggest that the tension between the two can be seen as specifically linked to the cultural, ideological, and political climate of the period, rather than taken at face value as the opposition of tradition and radical emancipatory politics.

Historically, the WLM was known for its early critique and suspicion of male dominated mainstream politics and the state (Randall, 1998). This was partly the result of women's exclusion (directly and indirectly) from much professional and political work. In subsequent decades the relationship between feminism and the UK state was ambivalent and much discussed by both activists and theorists. Ranging from the wholesale rejection of the state as a site for engagement, to more statist or nuanced accounts suggesting it can be a constructive site for action, or at the very least an ambivalent one (Rowbotham, 1979, Franzway, Court et al., 1989, Rowbotham, 1996, Randall, 1998, Kantola, 2006, Chappell, 2013). Although the focus of this work is primarily on the relationship between feminist and professional working as opposed to the state, I ground my understanding of the state on approaches that synthesise poststructuralist insights with understandings from different feminist theories - recognising the state as plural rather than singular, a complex set of institutions, agencies and discourses (Franzway, Court et al., 1989, Watson, 1992, Randall, 1998, Kantola, 2006). From the perspective of analysing relationships between feminism and the state in the UK, these have been significant in opening up space for a consideration of this as not singularly oppositional.

As I go on to argue, marking council equalities working as outside the boundaries of the feminist movement 'proper' - for example, as critiques at the time (Coote and Pattullo, 1990, Halford, 1990) and new social movement theory (Melucci, 1989, Melucci, 1996, Porta and Diani, 1999) have suggested - does not fully capture the complexity of the views and working of my interviewees. This blurs the line between social movement and state, and shows the way in which people have chosen to work in this space to pursue gender equality. This is particularly relevant if we consider that organisational theorists have highlighted the way in which movements can bring social change through organisational behavior and policy (Zald, Morrill et al., 2005). From this perspective the work taking place on gender equality in local government can be seen as a key way in which social change has been driven by the women's 
movement. The local government initiatives I studied illustrate the key dimensions of this process: 1) through changing categorizations, justice claims and consciousness raising, and by changing assumptions about right actions and routine grounds and practices, 2) through surveillance and sanctions, and 3) indirectly through movement influence on public policy and agencies. In the first case the initiatives built a legitimate claim to address issues particularly facing women, or to put it another way, named the androcentric nature of the councils as institutions. They put in to place new structures and practices to address this. In the second case they monitored these new developments, and worked to integrate them into the councils' regimes of surveillance and evaluation. In the third case they acted to create and shape the policy of the councils as influential public agencies.

Several of my interviewees from the pioneering and the enthusiastic follower councils also made explicit references to their participation in, or experience of, the Women's Liberation Movement. For example, one recounted her participation in consciousness raising:

Wendy: '78 to '79 I lived in Sheffield and was part of a sort of, I lived in a household of very political people, and I was part of a women's group there... I would say more like a conscious raising group if anything, a group of women being supportive to each other who would meet occasionally to discuss kind of issues that affected them at the time. (Wendy, Women's Committee Chair, Pioneering Council)

Wendy clearly described her involvement in something seen to typify the WLM as a 'formative' experience. Another interviewee also remembered the now iconic Ruskin conference as:

Absolutely chaos [laughs] [FJR: In what way?] Well I mean hugely exciting because there were lots of women around...but also kind of frustrating in that, that nothing ever got properly agreed, there was never any kind of you know, 'this is what we're going to do’. (Betty, Equality Consultant, Enthusiastic Follower Council)

This comment from Betty captures her enthusiastic involvement in this seminal feminist conference, while also expressing her ambivalence about the way it was organised. As I go on to argue, this is a salient element in positioning the council equality workers in relation to the feminist movement.

Several of my interviewees recounted visiting Greenham Common, with one describing it as doing 'the whole Greenham thing'- suggesting it is something standard and taken for 
granted, akin to a shorthand, within an understanding of what feminism means. However, this connection to the WLM was not the case for all of the interviewees who had been involved in the women's initiatives. This was particularly the case in the late adopter council where none of the interviewees recounted being involved with it. Broadly though, the explicit involvement of many of the council workers at some point in what has been considered the core of the WLM supports the argument for the connection between the two.

If we consider the issues the interviewees raised as important in describing their feminist views, and if we look at the topics they were working on, there is a significant degree of overlap between the WLM and the council initiatives. The views of the workers who described themselves as feminist encompassed a mixture of the ways in which feminist theory is usually schematised (i.e. radical, socialist, liberal) (Tong, 1998). When we consider the areas worked on by the council women's initiatives, using the archival documents as well as the interviews, many of these map directly onto the seven demands of the WLM outlined earlier. Those given most attention were equal pay, education, and childcare, but work was also taking place on legal and financial independence, and sexuality, either directly or through the funding of external groups such as rape crisis centres or lesbian groups. Thus we can further see the links between the WLM and the equality workers' activity within the councils.

The discussion so far has begun to explore the way in which ideas, individuals and ways of working can span the boundaries of what is usually seen as the feminist movement. It is also valuable to consider what impact having feminist views actually had on the work taking place, particularly given that I left the definition of 'feminist' open during the interview process. The notion of social movement ideas becoming institutionalised over time is a common theme in the literature as discussed earlier. However, this does not elucidate the actual practices through which feminist ideas can shape an organisation, nor consider the individuals seeking to drive this as Dean has pointed out (Dean, 2010) - which I seek to do here. I now discuss the ways the workers felt their feminist views affected their work, and their motivations for working on gender equality in local government. Historically there has been an ambivalent and contested relationship between feminist ideas, organising and professional working. I argue that my interviewees' orientation to making practical change provides a useful perspective from which to see both their continuity with the WLM and feminist movement, and a way of reconciling the feminist with the professional. 


\section{The Significance of the Workers' Feminist Views for their Council Working}

All of the interviewees felt that their feminist views were significant in the way they worked. They saw their position as one where they could use their views to influence people within the council to work in new and different ways. One of the interviewees also discussed the importance of feminist views in the staff they hired:

Harriet: I think it was significant, I mean $[\mathrm{X}]$ who was the first admin officer was, is a feminist, and that made a big difference.

FJR: In what way?

Harriet: Because she was on message, she understood why we did things. I mean one of the frustrations I had was that I quite often had to start from the beginning, like eh oh we want to set up a centre for women's health: 'oh why?'. (Harriet, Women's Officer, Late Adopter Council)

This reflects the importance of having workers who recognised and understood gender inequality, and could explain this to other people within the council. It was obviously important to have staff who could see the underlying issues rather than paying lip-service to them. Scholarship examining gender equality workers, including femocrats, in later periods has also suggested that such individuals feel their feminist views have significance for their working. For example, with Eisenstein (1995) suggesting Australian national government workers felt they had a feminist 'conscience' which kept their actions in check.

Along similar lines, other interviewees described how their feminist views enabled them to keep going in a challenging environment and to fundamentally understand the issues being worked on. For example:

Well if you didn't I don't think you understood, you could understand the challenges or the issues that you were working on. (Geraldine, Women's Unit Worker, Pioneering Council)

Here again, the idea of feminist knowledge and understanding of the working of gender inequality is deemed essential to being able to carry out their work. In developing the idea of 
the professional feminist this knowledge is a core component, linking the workers to feminism as a social movement despite their professional position within local government.

Other interviewees described how their views shaped both the way they organised and the issues they worked on. This supports the findings of earlier research as well as my own examination of the women's initiatives' working. For example one recounted a sense it brought for her:

that we don't have to operate in the kind of traditional, the sort of masculine way that, the masculine kind of adversarial way of relating to one another. And that women can do things differently when they talk about things. That impacted on how I think we ran the actual committee meetings. (Wendy, Women's Committee Chair, Pioneering Council)

Whether or not one subscribes to the idea that women relate to each other differently to men, this extract shows the way this interviewee's feminist views shaped the issues she sought to address through the council initiative, and the way in which this was organised. As discussed above, this clearly challenged the priorities and organisational norms of the council. Having said this, of course the question of which and how these had concrete impact on the councils, and indeed their wider significance cannot be fully answered by the reflections of those involved. Although beyond the scope of the present article, it is valuable to reflect on the limitations of such practice - both the constraints and resistances of the institutional context, and the representation of feminism held by the individuals involved.

From the perspective of social movement theory, the idea that both insider and outsider working contribute to bringing about social change is not controversial, highlighted in relation to the women's movement by Threlfall (1996) and MacKay (2008). Historically insider and outsider working add different elements to a change project, even if they are not planned in conjunction with each other, or indeed can be actively opposed. I suggest that my data reveals the way in which local government has been, and remains, a potentially useful site for both insider and outsider working on issues of gender equality. It is worth considering, theoretically and practically, as a location of feminist work. 
Having considered how the gender equality workers relate to feminism and the WLM lays the ground for a discussion of how we should situate them in relation to theorising about activists and organisations. As discussed earlier, those working on gender equality without being activists in the traditional sense, or politicians, have not received a huge amount of attention, particularly in the UK context, and during this time period. This is connected to the way in which discourses about feminist organising have historically positioned it as antithetical to professionalism - professional here defined broadly as paid to undertake a role in a skilled capacity - as opposed to being a member of a specific profession (Friedson, 1994). Examples of this positioning include Segal (1979) and Wainwright (1979), who highlighted how the WLM, 'meant a different way of organising, a way of organising which does not restrict political activity to "the professional"' (Wainwright, 1979: 13). Later work such as Bouchier (1983) and Setch (2000) continued to reflect this, for example highlighting controversy over organisation and payment for work, and what this meant in relation to feminism and professionalism. Although undoubtedly linked to the ambivalent relationship between feminism and the state during the same period as discussed earlier, I focus here on the more rarely examined relationship between feminism and professional working.

Jonathan Dean's work has examined the way in which this history has also resulted in a particular way of thinking about what is radical within feminism. He suggests that this should be recast as its world-building capacity rather than its location in a particular (non-state, autonomous) space (Dean, 2010). The idea of the femocrat (the feminist bureaucrat) has been the most developed way of examining those working with a feminist agenda within bureaucratic organisations (Franzway, Court et al., 1989, Eisenstein, 1995, Eisenstein, 1996, Chappell, 2002). However, I argue that this notion does not fully describe the position and working of my municipal feminist sample. Not only is feminism significant in shaping the professional life of my interviewees, but their work within the councils represents a significant challenge on an organisational level — rather than aligning with existing bureaucratic structures. I also posit the focus of the gender equality workers on making practical change as a key element in understanding them as professional feminists, and reconciling these usually opposed concepts. This allows us to see their continuity with the aims and approach of the WLM, as well as explaining their rationale for choosing as individuals to engage in seeking change through local government. This shifts the relationship between the feminist movement and local government initiatives away from being a process of inevitable social movement institutionalisation. Instead we can view the 
decision to work within local government as a specific practical strategy for bringing about social change, and more broadly as a particular element within a constellation of different approaches to feminist working.

\section{Occupying a challenge position}

In the pioneering council, the interviewees' accounts of their work revealed the novel and challenging nature of what they were doing within the council. For example, one interviewee from the inception of the initiative at the beginning of the 1980s recounted:

Geraldine: the women's unit was very much an activist in terms of its whole existence was very much about trying to mobilise people to take action to to you know seek redress or to you know improve courses etc. We were very engaged with all of those...individuals as well as activist groups. And that was probably part of the problem in terms of the political dimension.

FJR: In what way?

Geraldine: Because you were challenging council policies you know from, on one side we were working internally with departments to improve council policies and where there was no change or that didn't work we would then mobilise the voluntary sector and individual women to then challenge the council and empower them to do that. So you know from the council's point of view it was like, hold on, this is an internal provision that is going out there and asking the public to challenge the council's own processes. So you know there was a bit of a conflict there or tensions there. (Geraldine, Women's Unit Worker, Pioneering Council)

This interviewee went on to explain various ways in which the unit had worked on issues inside the council while also facilitating women in the local area to lobby and campaign, including negotiating the complex structures of the council. She stressed how this placed the unit in a difficult position in relation to the rest of the council — pushing against it from within. This illustrates the extent to which the women's initiative was operating in ways even the interviewee herself referred to as 'activist'. That is to say, they were challenging in order to shape the council's agenda and working. Although some of the workers' activities (such as bringing a gendered analysis to policy) have been included in the definition of the femocrat 
(Eisenstein 1996), suggesting this partly describes their working, Yet not fully, as despite being based in a bureaucratic organisation, this interviewee was not working in a bureaucratic way that would be suggestive of the term femocrat. Eisenstein (1995) and Charles (2004) discuss the idea that femocrats are accepting of bureaucratic forms of organising, and can see this as a necessary compromise in their work. In the enthusiastic follower and late adopter councils, interviewees were also extremely clear about their role in the first initiatives being to challenge the traditional agenda and working of the council. The following quotation illustrates this:

We were trying to change the whole culture and dynamic of the council house, so it was like, oh these women are on another mad one. (Emily, Women's Officer, Enthusiastic Follower Council)

This interviewee explained that they intended to challenge the, 'hierarchical power structure' and, 'traditional way of working' to create something new. In some cases this even went so far as experiencing active hostility from the rest of the council which had to be fought, as another interviewee described:

I'm sure there were lots of people in the council that didn't want it [laughs]. Well I mean that was obvious when we were trying to have that [inaudible] round departments and trying to look at getting people to represent the issue and all that sort of thing. People just thought it was a waste of time, what was the point of having it. (Barbara, Women's Unit Worker, Late Adopter Council)

The interviewees themselves enunciated their differences from the other bureaucratic workers of the council, again distinguishing them from femocrats who might embrace this way of working. However, they also stated their separation from people outside the council, and talked about tensions which could arise with campaigners. This supports the argument for the distinctiveness of professional feminist working, in this case within local government, rather than regarding it as a linear institutionalisation of the feminist movement. In his work looking at feminist demands on the state and feminist civic society organisations, Dean suggests that the 'radical' in feminist working relates to its ability to enable the imagining and creation of new ways of thinking about the world (Dean, 2010). This is useful in my examination of a different arena of feminist working (local government employees), where the council equality workers sought to create new ways of thinking and working within the councils - introducing topics, approaches, spaces and methods that challenged their modus operandi. 
When asked whether they ever felt conflict between their professional role and feminist views, one interviewee from the enthusiastic follower council explained their position as follows:

Emily: I didn't ever because...I was appointed to be a professional feminist and do very practical things within my particular brief and do, make arguments backed up by evidence in certain fora, like the management team fora, so that's what I was paid to do. The committee had declared itself to be about challenging discrimination and inequalities and I felt that my politics matched that exactly. They were my life-long politics and they matched that. (Emily, Women's Officer, Enthusiastic Follower Council)

This unprompted and specific enunciation of the 'professional feminist' reflects the idea that the feminist politics being played out in a professional arena were nonetheless feminist for this location. As I discussed earlier, this apparent oxymoron has not been much explored in the context of the UK - arguably because it doesn't fit neatly with the ways of working seen to typify the WLM and feminist movement, nor as constitutive of 'state feminism'. My interviewees themselves repeatedly emphasised their contrasting approach to that of bureaucrats who fitted in with the existing organisation and priorities of the council. One interviewee illustrated this as she described people drawing her attention to the role when it was advertised:

I suppose there was a feeling that, from people within community work etc, that they didn't want it to be a kinda bureaucratic post they wanted it to be filled by somebody who was kinda grass roots as opposed to a bureaucrat. (Harriet, Women's Officer, Late Adopter Council)

One of the ways in which the initiatives sought to challenge the traditional structures and processes of the council was through opening it up to women in the community using consultation. For example, one interviewee at the enthusiastic follower council recounted developing the system of consultation with and co-optation of local women in order that their work be informed by a more representative understanding of local women. This women's initiative also specifically held women only meetings to support their participation - and interviewees recounted the challenge they faced gaining agreement for this. Similarly, another interviewee explained their attempts to make events and meetings accessible: 
I think because we could shock people a bit more then because we could take our meetings out, we could organise things for international women's day, safety workshops for women. We could do things, I think they'd say nowadays a little bit out of the box. (Margaret, Women's Advisory Group Chair, Late Adopter Council)

This drive to be inclusive and engage with women reflected a working principle central to the feminist movement being taken up with great effort by the council workers. Although arguably a progressive intention, this was not without controversy in relation to who and how this took place. There does not appear to be evidence that working within the council presented an easier option for interviewees than traditional activist channels, although it is not a path that everyone would be able to or want to follow. As discussed earlier, the attempts of the workers to think, 'out of the box' is an element to understanding their feminist challenge position within the council, and this is supported by Dean's suggestion that radicality relates to the capacity of work to enable things to be seen in new ways rather than the site in which it is located (2010).

Another facet of the equality workers' challenge position arguably results from their situation neither fully inside, nor outside, the council as an organisation or the feminist movement. As mentioned earlier, at points the interviewees reflected on facing hostility from feminist activists outside the council, and also from left-wing activists including trade unions. Thus they were clearly distinct from the activists outside the council, while sitting in a position of challenge within the council itself. One of the interviewees from the late adopter initiative eloquently expressed this difficult position saying:

One of the challenges I found on the job was that kind of, one you're a woman, you've got women's groups expecting something of you because you work in an official women's unit. And then you had to deal with the kind of like, the bureaucracy of working for a council. Em and I sometimes found it quite difficult because you never knew where you fitted, because the women's groups hated you because you weren't doing enough for what you wanted. The council folk hated you because [laughs] they thought you were trying to change things inside. And you were stuck in the middle going, 'arghhh' [laughs]. (Barbara, Women's Unit Worker, Late Adopter Council)

This interviewee went on to explain how, 'stuck in the middle' they could feel, sympathetic to the external groups as well as stressed by their demands on the council. Indeed this at times uncomfortable positioning is something which has also been reported in relation to 
other scholarship on gender equality workers in different organisations and time periods. For example, Mazur and Stetson (1995) and Ebyn and Turquet (2013). These conflicts are insightful as I situate the workers and the initiatives in relation to existing work on social movements and activists. Firstly, the conflict experienced (in some instances) with the left supports the argument for the distinctiveness of municipal feminism in relation to the municipal socialism of the period. The women's initiatives evidently presented a challenge to the leftist establishment in some cases. Secondly, it could be tempting to read the conflict experienced with some feminist activists as a sign of discontinuity between the feminist movement and the initiatives. However, I think that 1) given the diversity of views within the WLM and feminist movement and 2) the considerable affinities between the interests and working of the movement and those of the women's initiatives, this conflict is more logically read as an example of the multiplicity of the identities and methods of the WLM, and wider movement. This supports the argument introduced earlier, that while connected to the feminist movement more broadly, the professional feminist workers are not simply its linear institutionalisation, nor femocrats working in sync with the bureaucratic organisation of the councils. Braidotti's theorisation of the nomadic subject — as dynamic and changing; an 'outsider within' (Braidotti, 2002: 5) makes a useful contribution here to understanding this subject position. The idea that the workers inhabit a nomadic position — neither fully activists outside, nor accepted within the council organisation - goes some way to describing both the costs and opportunities this holds for them as professional feminists. The space occupied by the workers is one where significant interpretation takes place in relation to the discursive politics of gender equality. Their nomadic position is also a productive one which has significant implications for the way in which legislation and policy are stretched, bent, shrunk and fixed (Lombardo et al, 2009) in the process of being enacted by and within councils. In attempting to theorise a professional feminist space and subjectivity Braidotti's work helps to connect both to the WLM and beyond it: her insistence on nomadism as a component of becoming rather than as a rhetorical device, arguably connects us back to the prefigurative practices of the WLM, where living and enacting ideals was crucially important. This sits alongside what more recent attempts to theorise and enact modes of change have necessitated - a creative, imaginative dimension. In Braidotti's account this imaginary is explored in the possibility of the becoming subject where, 'the space of becoming is one of dynamic marginality' (Braidotti, 2002:78). Seeking to develop an account of this subject within a positive casting of difference, the notion of becoming takes place in the in-between, intervals and transitions between differences. This vision of the subject helps 
to develop my account of the multiple, conflicted, yet also constructive position of the professional feminist. This contributes to disrupting the tendency to think about the WLM and feminism as divided into different schools and approaches.Instead we can regard it as a project with material, political, cultural and imaginative dimensions, conceivable in different modes and locations - that can be regarded as functioning elements within a constellation, as opposed to alternatives. As I have shown, the women's initiative workers embodied this, striving to challenge the working of the councils, in terms of the issues addressed and modes of organising. This 'visioning', beyond the feminist bureaucrat, has been identified as important to feminist activity in different arenas - from the theorising of gender mainstreaming, to Dean's work suggesting that feminist radicality inheres to its worldbuilding capacity.

\section{Motivated to Make Practical Positive Change}

By examining the ideas and working of the equality workers I have shown how they span the feminist and the professional. Firstly, I found that feminist knowledge and understanding is regarded by the workers as necessary to carry out their professional roles, making feminism integral to their professional capacity. Secondly, they seek creatively to challenge within the council to achieve feminist aims, pushing outside the definition of the femocrat to envisage topics and modes of working in new ways. The workers carry this out in paid roles which at times positions them in conflict with activists outside their organisation, and people within it. Thirdly, I seek to argue that the orientation of the equality workers towards making practical change in people's lives, in relation to gender equality, functions in several ways. It presents a key way to understand their continuity with the WLM and feminist movement, as well as their distinctive contribution to feminist activism as a multifaceted project. This practical drive is an element in bringing about social change. As discussed earlier, social change is often enacted through change in organisations' — such as councils — agendas, policies and practices. Thus 'professional feminist' is one way of understanding this particular position within the broader arena of feminist thought and activity.

All of my interviewees considered themselves feminists, and some had experience of activism as part of the women's liberation movement. Significantly, regardless of their connection to the WLM, the majority of my interviewees expressed the rationale for their work as the aim to engender practical changes in women's lives. This arguably chimes with 
research discussed earlier in relation to council politics, suggesting that community work was an important precursor to council office holding for women (Martlew, Forrester et al., 1985). Considering the background of my interviewees, even those without experience of the WLM had been involved in community work, often with women. This was the case for all but one interviewee. For example one from the enthusiastic follower council with a background in trade unions, further education and community work recounted how she became politicised and realised influencing the council could bring concrete change to people's daily lives.

She emphasised acting to make change, and convincing others of what was needed, rather than discussing or theorising in a more abstract or universal way. Similarly one of the interviewees in the late adopter council explained:

Well first of all I was a community worker, and I worked in the East end of [X]. And most of my work was working with women, so, working with poor women in $[\mathrm{A}],[\mathrm{B}]$, [C], and at that point got involved in the development of women's health fairs, in the ' 80 s, a lot of women's health groups, em and generally that was the start I suppose of a bigger women's equality movement. (Harriet, Women's Officer, Late Adopter Council)

This interviewee reflected on the centrality of community work to her life, and what she felt driven to pursue. She went on to talk more about the different community development projects she had carried out, stressing that it was women who were key to this in terms of anti-poverty, health, and education work - for her gender was central to broad social change.

Another interviewee explained her background and frustration with traditional politics in contrast to thematic work within the council saying:

As a teenager I was a member of the Labour Party Young Socialists and flirted with Militant quite a bit and that sort of thing, but in the end made the decision that that kind of party politics route didn't suit me. And to be honest em [FJR: Why?] a lot of the reason for that was because it was so male dominated, very, very male dominated. I suppose that was the main reason. I also didn't like the confrontational side of politics to be honest I just couldn't be bothered with it. I just thought life was too short [laughs]. (Barbara, Women's Unit Worker, Late Adopter Council)

So working directly with individuals and communities to support them to bring positive changes in their lives, and make their voices heard, was important to all of the municipal feminist interviewees. This was the case whether or not it took an explicitly feminist form or 
title. When we examine the way in which they reflect on the work they undertook within the women's initiatives, the desire to see concrete results and address problems faced by women is palpable. For example, in the pioneering council:

I think there was good stuff done by the GLC women's committee, but I think I, along with a number of other people, shared a bit of a concern that it was a bit too much and too scatter gun and not sufficiently focused...so I think what was very clear in my mind was focus, um, and that you couldn't do everything. (Rachel, Women's Officer, Pioneering Council)

This illustrates the desire of the interviewee to create clear and concrete outcomes, through being focused on specific goals — rather than taking a, 'scatter gun' approach. This also reflects a sense of responsibility for the outcomes achieved - something that is part of professional conduct, supporting my argument that my interviewees are best understood as professional feminists.

Another interviewee at the pioneering council surmised her goals in relation to changing women's lives in a quotidian sense saying:

my commitment to want to see women achieve in employment was something that was important to me in terms of changing employment practice of the council. Erm I suppose issues to do with things like improving childcare, improving opportunities for women, improving nursery provision, all that sort of stuff. And then improving, you know funding organisations like Women's Aid um stuff like that that was very important. And all that came from you know, my feminism was you know behind my motivation to become involved in those sorts of things. (Wendy, Women's Committee Chair, Pioneering Council)

This outlines a range of practical outcomes, driven by feminist views, that I argue is key to positioning professional feminists. The other interviewees at the pioneering council also talked about their aims to change attitudes and lives in relation to sexual and domestic abuse. In the enthusiastic follower council the interviewees were similarly very focused on practical rather than esoteric action. As one recounted her desire, 'to change things' saying she realised you had to have a political voice. 
Another interviewee reflected on the ambivalence towards the women's initiative of some feminists, but stressed that on balance it provided a stable base from which to create concrete change:

I thought it was worth doing because it gave a, it gave a kind of source, a sort of stable source of being able to do something. And I also thought the recognition of it being taken as a kind of important, you know that sort of external recognition of it being an important aspect I thought was important, you know that that was a, that was quite a critical issue um from my point of view and um others. That you know, that women's equality is something which is not just of concern to you know a bunch of radical women, but is something that actually is of concern to, or should be of concern to organisations you know. I thought that was an important step forward. (Betty, Equality Consultant, Enthusiastic Follower Council)

This illustrates recognition of the issue as a dimension of the claims being made. As discussed earlier, this is a constituent part of bringing about social change through the medium of a large organisation. Yet at another point, this same interviewee explained her problem with discussion and theory as opposed to affecting change for women, suggesting that recognition was not sufficient. Having originally argued with her father about the importance of principles over compromise, she described how her views shifted through her experience of outsider activism of the late 1960s, to working in local government:

when I was at university you saw, 'cos I went to Sussex in 1969, so just after the paint throwing over the American ambassador, and the Vietnam war and all of that, Tariq Ali and so on. And Sussex was a hugely political place, and yet so much of it just seemed so kind of esoteric and I got quite frustrated by that. Because it wasn't about how do we make things better for people, it was about how can we get our ideas recognised as right, and other people's ideas recognised as wrong. And while part of me is drawn to that on a kind of intellectual basis, I also think, well, it's about making a difference to people, that's what we always ought to have in our minds. (Betty, Equality Consultant, Enthusiastic Follower Council)

So although engaged with politics and interested in discussing ideas carefully, she ultimately wanted to be, 'making a difference to people' rather than winning arguments. We can see then why local government might be appealing for someone with these beliefs and 
motivations. This interviewee went on to describe their attendance at the Ruskin conference as really exciting, yet also frustrating due to the lack of concrete outcomes.

We can read Betty's stress on making change in women's quality of life as pertaining to socioeconomic redistribution - such as ensuring money and services were available to them. This sits in conjunction with her statement of the significance of the existence and acknowledgement of the women's initiative - signifying the need to recognise and validate women. Thus without denigrating the importance of either element, her preference can be seen to reflect a choice of which dimension of this project to undertake. This attempt to bring together and synthesise different concerns and approaches is also something which can be seen reflected in later work on the 'mainstreaming' of equalities (Rees, 1999).

Another interviewee explained that having attended the consultation meetings carried out by the women's initiative, she was determined to apply for the women's officer post at the last minute. This was because she wanted to ensure it was done by someone with a practical, and not just academic, understanding of women and their lives. She recounted:

I sat on a row of women and there were three women, please don't be offended, three academic women sitting next to me who were, who had the job packs for these women's officers' posts, and were talking about how they were applying to do this work. And I was kind of out in the sticks, in the nuts and bolts of all sorts of horrendous things that happened really for those young women that I worked with. And I was so horrified that the people, the women who might take these roles would take a theoret, had a theoretical feminist approach kind of solely really, um to the work, that I came home, the jobs closed 36 hours later. I came home and the following morning I got the job pack. (Emily, Women's Officer, Enthusiastic Follower Council)

This interviewee really enunciated the argument I am making about the importance of practical outcomes for the professional feminists. The fact she did this while also conscious of my own position as an academic woman emphasises its significance for her, and we laughed about this when she raised the point. For Emily, her experience of working in the community with women and striving to support them, was a fundamental part of the women's officer's role. It was this that drove her to pursue the work in local government, in contrast to taking a more academic or theoretical approach to feminism. 
In the late adopter council too, the stress on the practical change which the women's initiative had the potential to bring was evident in the interview data. One interviewee described the compromise position of attempting to be a feminist within a bureaucratic organisation. This was presented as a contrast - she did not see herself as a bureaucrat (or indeed femocrat). This supports my argument that professional feminist equality workers occupy a connected but distinct position to the feminist movement. The value of this nomadic position in her mind was being able to make change and influence, a dynamic place as this quotation illustrates:

I suppose feeling that I was in a very privileged position because I was being able to speak to decision makers, policy makers, em heads of service delivery, and persuade them that they could do things differently. So I mean I think that was what drove me, and seeing that you know when we developed the [training centre] for example, we had 20 women every year who graduated and went on to do things that they would never have done... actually you were seeing women who had been supported into better outcomes. (Harriet, Women's Officer, Late Adopter Council)

This interviewee herself talked in terms of concrete, 'better outcomes' for the women involved with the project, as what drove her work. Another interviewee spoke of how her experience with younger women led to her feeling she needed to take action to change their lives for the better as she felt things were getting better not worse for them.

One interviewee gave an eloquent account of the way in which local government working differed from both formal and activist political routes to making change. This represents the crux of my argument regarding the workers: the centrality of practical change to their motivations, and their distinctiveness in comparison to the idea of the femocrat. Working for the council represented a way to really make a difference, rather than through confrontational politics or activism:

I'd left university because I didn't like it and went to work for the council. And well, as I say, realised you could actually make a difference in your working life and not just in political life so, and that's why every job that I've done has been about something that I'm quite passionate about. Came from a very deprived background myself so was interested in that kind of, the whole equality issue completely, about women, about class, about race etc. So yeah, so just was always interested in that em, and then as I say when the women's unit job came up I just thought it would be a perfect way of doing something 
which I cared about passionately, but could actually do make a living out of it and actually make a difference at the same time. (Barbara, Women’ Unit Worker, Late Adopter Council)

As this comment raises the issue, it is also important to acknowledge the significance or indeed necessity of being able to, 'make a living out of it' for the workers, rather than denigrating it as a motivating factor which has been the case in some discussion in feminist literature of that period. Being able to participate in activism requires time and financial support, affecting who can be involved. From the perspective of those who must work for a living, it is evident how pursuing gender equality in local government could be an appealing path. Of course, the politics of who is and is not able to undertake different types of feminist activity, paid or unpaid is multi-faceted. Socio-economic status and education for example being key axes which would impact on this.

The common features characterising the workers as professional feminists are: using knowledge and understanding of feminism to carry out work on gender equality; being paid to work on gender equality in a professional capacity while occupying a challenge position in relation to the councils' agenda and organising; being motivated by bringing practical positive change to people's lives. I have argued that these individuals sit in a space between outside activists and insiders of the local state, but that their position is not adequately described by the idea of the femocrat. The imaginative and challenging element of their professional feminist work within the councils, akin to the visioning required for successful gender mainstreaming, and radicality as suggested by Dean, means that we should consider their working as part of a broader constellation of feminist action.

\section{Conclusion}

This article has examined 1980s UK local government gender equality workers in relation to feminism, social movements, and locations and modes of feminist organising. Using interview and archival data I developed the concept of the 'professional feminist', drawing on the work of Dean and Braidotti. I argued that this more accurately describes the local government workers than the 'femocrat'. A range of socio-historical and disciplinary factors have led to the positioning of feminist and professional working as somewhat antithetical to each other, particularly tied to the history and scholarship of the Women's Liberation 
Movement in the UK. Although attention has been given previously to the relationship between feminism and the state, and indeed formal politics, there has been less attention paid to the close analysis of those working professionally, though not in an elected capacity to further gender equality. This is particularly the case in the context of UK local government, and phenomena of municipal feminism. Contributing to addressing this gap in scholarship I began by showing the extent to which the workers considered themselves feminist, their relationship with the WLM, and the significance of this for the work they undertook within the councils. Only some of my interviewees had been directly engaged with the activism of the WLM, yet the ideas and issues that occupied it overlapped significantly with those of the council workers, blurring the traditional delineation of the boundary between social movement and state. I argued that the feminist identification and knowledge of the workers, and which was deemed necessary for their professional work, characterises them as professional feminists, along with the challenge position they occupied within the councils. The workers are positioned neither fully inside the council, nor outside it as activists, despite their connections to both. As my interviewees discussed, this can be both a difficult and productive place to inhabit, as they act to interpret and envisage new ways of thinking and working within the councils. This challenge position in particular distinguishes them from the notion of the 'femocrat'. Similarly, I argued that the orientation of the workers to bringing about practical change, and their conscious choice to work within local government, is both a link to, as well as distinction from, other feminist activity. I drew particularly on the work of Dean and Braidotti in defining this subject position as one that productively disrupts the usual distinctions of where and in what way feminist activity takes place (often seen as either outside or inside the state). The professional feminist worker arguably can't be fully described in these terms, and as I have suggested, represents a distinctive contribution within the broader array of feminist strategies for bringing about change at different points in time and locations. Instead of regarding these actors as straightforwardly aligned, unaligned or as 'institutionalised' elements of the feminist movement, the notion of the 'nomad' highlights their motion, and the productivity in this. In addition to this contribution to the rebalancing of how different approaches to feminist working are understood and evaluated, this article also reflects the methodological value in drawing across multiple disciplines in analysing social change strategies. Employing feminist, social movement and organisational insights in relation to each other enables a fuller and more balanced, contextualised account of the micro and meso phenomena at hand. 


\section{References}

Acker, J. (1995). Feminist Goals and Organizing Processes. Feminist Organisations: Harvest of the New Women's Movement. M. M. Ferree and P. Y. Martin. Philadelphia, Temple University Press: 137-144.

Allan, E. J. (2008). Policy Discourses, Gender and Education. London, Routledge.

Arendt, H. (2005). Essays in Understanding, 1930-1954: Formation, Exile, Totalitarianism. New York, Schocken Books.

Bashevkin, S. (2006). Tales of Two Cities: Women and Municipal Restructuring in London and Toronto. Vancouver, UBC Press.

Blau, P. M. (1956). Bureaucracy in Modern Society. New York, Random House.

Bouchier, D. (1983). The Feminist Challenge. London, Macmillan.

Braidotti, R. (2002). Metamorphoses: Towards a materialist theory of becoming. Cambridge, Polity Press.

Brownill, S. and S. Halford (1990). 'Understanding Women's involvement in local politics: How useful is a formal/informal dichotomy?' Political Geography Quarterly 9(4): 396-414.

Bruegel, I. and H. Kean (1995). 'The moment of municipal feminism: gender and class in 1980s local government.' Critical Social Policy 15: 147-169.

Button, S. (1984). 'Women's Committees: A study of gender and local government policy making.' SAUS Working Paper 45.

Cerwonka, A. and L. H. Malkki (2007). Improvising Theory: Process and Temporality in Ethnographic Fieldwork. Chicago, University of Chicago Press.

Chappell, L. (2002). 'The 'Femocrat' Strategy: Expanding the repertoire of Feminist Activists.' Parliamentary Affairs 55: 85-98. 
Chappell, L. (2013). Monolithic to Differentiated state. The Oxford Handbook of Gender and Politics. G. Waylen, K. Celis, J. Kantola and S. L. Weldon. Oxford, Oxford University Press: 603-626.

Charles, N. (2004). 'Feminist Politics and Devolution: A Preliminary Analysis.' Social Politics 11(2): 297-311.

Cockburn, C. (1977). The Local State. London, Pluto Press.

Coote, A. and B. Campbell (1982). Sweet Freedom. London, Picador.

Coote, A. and P. Pattullo (1990). Power and Prejudice: Women and Politics. London, Weidenfeld and Nicolson.

Cowman, K. and L. A. Jackson (2005). 'Middle-Class Women and Professional Identity.' Women's History Review 14(2): 165-180.

Dean, J. (2010). Rethinking Contemporary Feminist Politics. Basingstoke, Palgrave Macmillan.

Edwards, J. (1988). 'Local Government Women's Committees.' Local Government Studies 14(4): 39-52.

Edwards, J. (1989). 'Women's Committees: A model for good local government?' Policy and Politics 17(3): 221-225.

Edwards, J. (1995). 'The Feminist Case for Local Self-government.' Local Government Studies 21(1): 82-98.

Eisenstein, H. (1989). 'Femocrats, Official Feminism, and the Uses of Power: A Case Study of EEO Implementation in New South Wales, Australia.' Yale Journal of Law \& Feminism 2(1).

Eisenstein, H. (1991). 'Speaking for women? Voices from the Australian femocrat experiment.' Australian Feminist Studies 6(14): 29-42.

Eisenstein, H. (1995). The Australian Femocratic Experiment: A Feminist Case for Bureaucracy. Feminist Organisations: Harvest of the New Women's Movement. M. M. Ferree and P. Y. Martin. Philadelphia, Temple University Press: 69-83. 
Eisenstein, H. (1996). Inside Agitators: Australian Femocrats and the State. Philadelphia, Temple University Press.

Eyben, R. and L. Turquet, Eds. (2013). Feminists in Development Organizations: Change from the margins. Rugby, Practical Action Publishing.

Foucault, M. (1972). The Archaeology of Knowledge. London, Tavistock Publications.

Franzway, S., et al. (1989). Staking a Claim: Feminism, bureaucracy and the state. Cambridge, Polity Press.

Freeman, J. (1970) The Tyranny of Structurelessness.

Friedson, E. (1994). Professionalism Re-Born: Theory, Prophesy and Policy. Oxford, Polity Press.

Goss, S. (1984). Women's Initiatives in Local Government Local Socialism? Labour Councils and New Left Alternatives. M. Boddy and C. Fudge. Basingstoke, Macmillan: 109-132.

Green, S. F. (1997). Urban Amazons. Basingstoke, Macmillan.

Halford, S. (1990). Local Politics, Feminism and the Local State: Women's Initiatives in British Local Government in the 1980s. Graduate School of Arts and Social Studies. Falmer, University of Sussex. PhD.

Halford, S. (1992). Feminist change in a patriarchal organisation: the experience of women's initiatives in local government and implications for feminist perspectives on state institutions. Gender and Bureaucracy. M. Savage and A. Witz. Oxford, Blackwell: 155-185.

Halford, S. and P. Leonard (2001). Gender, Power and Organisations. London, Palgrave.

Harriss, K. (1989). 'New Alliances: Socialist-Feminism in the Eighties.' Feminist Review 31(Spring): 34-54.

Kantola, J. (2006). Feminists Theorize the State. Basingstoke, Palgrave Macmillan.

Kantola, J. and J. Squires (2012). 'From state feminism to market feminism?' International Political Science Review 33(4): 382-400. 
Katzenstein, M. F. (1998). Faithful and Fearless: Moving Feminist Protest Inside the Church and Military. Princeton, Princeton University Press.

Lombardo, E., et al. (2009). Conclusions: A critical understanding of the discursive politics of gender equality. The Discursive Politics of Gender Equality. E. Lombardo, P. Meier and M. Verloo. Abingdon, Routledge: 186-203.

Lovenduski, J. (2007). Unfinished Business: Equality Policy and the Changing Context of State Feminism in Great Britain. Changing State Feminism. J. Outshoorn and J. Kantola. Basingstoke, Palgrave Macmillian: 144-163

Lovenduski, J. and V. Randall (1993). Contemporary Feminist Politics: Women and Power in Britain. Oxford, Oxford University Press.

MacKay, F. (2008). The state of women's movement/s in Britain: ambiguity, complexity and challenges from the periphery. Women's Movements: Flourishing or in abeyance? S. Grey and M. Sawer. Abingdon, Routledge: 17-32.

Martlew, C., et al. (1985). 'Activism and office: Women and local government in Scotland.' Local Government Studies 11(2): 47-65.

Mazur, A. and D. M. Stetson (1995). Conclusion: The Case for State Feminism. Comparative State Feminism. A. Mazur and D. M. Stetson. London, Sage: 272-291.

McBride, D. E. and A. G. Mazur (2010). The Politics of State Feminism. Philadelphia, Temple University Press.

Melucci, A. (1989). Nomads of the Present. London, Hutchinson Radius.

Melucci, A. (1996). Challenging Codes. Cambridge, Cambridge University Press.

Meyerson, D. E. and M. A. Scully (2003). Tempered Radicalism: Changing the Workplace from Within. Reader in Gender, Work, and Organization. R. J. Ely, E. G. Foldy and M. A. Scully. Oxford, Blackwell: 266-272.

Outshoorn, J. and J. Kantola, Eds. (2007). Changing State Feminism. Basingstoke Palgrave Macmillan. 
Parker, I. (1992). Discourse Dynamics: Critical analysis for social and individual psychology London, Routledge.

Perriton, L. (2007). 'Forgotten Feminists: the Federation of British Professional and Business Women, 1933-1969.' Women's History Review 16(1): 79-97.

Porta, D. d. and M. Diani (1999). Social Movements: An Introduction. Oxford, Blackwell.

Randall, V. (1998). Gender and power: women engage the state. Gender, Politics and the State. V. Randall and G. Waylen. London, Routledge: 185-205.

Rees, T. (1999). Mainstreaming Equality. Engendering Social Policy. S. Watson and L. Doyle. Buckingham, Open University Press: 165-183.

Rowbotham, S. (1979). The Women's Movement and Organizing for Socialism. Beyond the Fragments. S. Rowbotham, L. Segal and H. Rowbotham. London, Merlin Press: 21155.

Rowbotham, S. (1996). Introduction: Mapping the Women's Movement. Mapping the Women's Movement. M. Threlfall. London, Verso.

Saunders, C. (2009). Organisational Size and Democratic Practices: Can Large Be Beautiful? Democracy in Social Movements. D. d. Porta. Basingstoke, Palgrave Macmillan: 150-170.

Scott, M. (2002). Women and Local Government - Dialogue, Deliberation and Diversity. The Changing Politics of Gender Equality in Britain. E. Breitenbach, A. Brown, F. Mackay and J. Webb. London, Palgrave Macmillan: 164-177.

Segal, L. (1979). A Local Experience. Beyond the Fragments. S. Rowbotham, L. Segal and H. Rowbotham. London, Merlin Press: 157-209.

Setch, E. G. (2000). The Women's Liberation Movement in Britain, 1969-79: Organisation, Creativity and Debate. London, University of London Royal Holloway. $\mathrm{PhD}$.

Stokes, W. (1998). 'Feminist democracy: The case for women's committees.' Contemporary Politics 4(1): 23-37.

Threlfall, M. (1996). Conclusion. Mapping the Women's Movement. M. Threlfall. London, Verso. 
Tong, R. (1998). Feminist Thought. A more Comprehensive Introduction. Boulder, Westview Press.

Travers, T. (1990). 'London After Abolition.' Local Government Studies 16(3): 105-116.

Wainwright, H. (1979). Moving Beyond the Fragments. Beyond the Fragments. S. Rowbotham, L. Segal and H. Rowbotham. London, Merlin Press: 211-253.

Walby, S. (2002). 'Feminism in global age.' Economy and Society: 533-557.

Watson, S. (1992). Femocratic feminisms. Gender and Bureaucracy. M. Savage and A. Witz. Oxford, Blackwell: 186-204.

Wright, M. (2002). LIfe after the GLC: Local Government and the Equalities Agenda in England. The Changing Politics of Gender Equality in Britain. E. Breitenbach, A. Brown, F. Mackay and J. Webb. Basingstoke, Palgrave: 178-198.

Zald, M. N., et al. (2005). The Impact of Social Movements on Organizations:

Environment and Responses. Social Movements and Organization Theory. G. F. Davis, D. McAdam, W. R. Scott and M. N. Zald. Cambridge, Cambridge University Press: 253-279. 